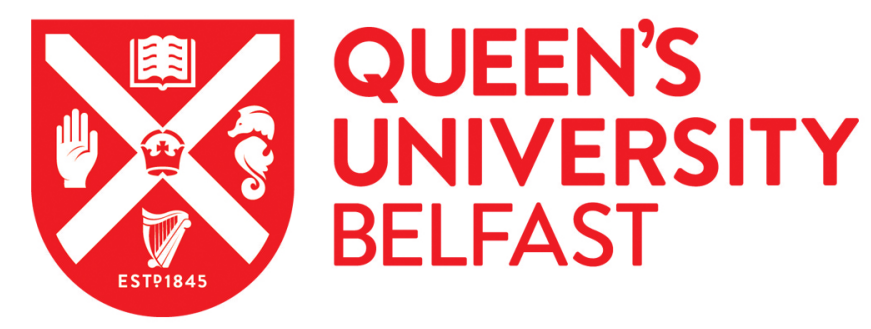

\title{
Giving Visibility to Urban Change in Rio de Janeiro Through Digital Audio-Visual Culture: A Brazilian Webdocumentary Project and its Circulation
}

Holmes, T. (2017). Giving Visibility to Urban Change in Rio de Janeiro Through Digital Audio-Visual Culture: A Brazilian Webdocumentary Project and its Circulation. Journal of Urban Cultural Studies, 4(1-2), 63-85. https://doi.org/10.1386/jucs.4.1-2.63_1

Published in:

Journal of Urban Cultural Studies

Document Version:

Peer reviewed version

Queen's University Belfast - Research Portal:

Link to publication record in Queen's University Belfast Research Portal

Publisher rights

(C) 2017 Intellect Ltd.

This work is made available online in accordance with the publisher's policies. Please refer to any applicable terms of use of the publisher.

\section{General rights}

Copyright for the publications made accessible via the Queen's University Belfast Research Portal is retained by the author(s) and / or other copyright owners and it is a condition of accessing these publications that users recognise and abide by the legal requirements associated with these rights.

Take down policy

The Research Portal is Queen's institutional repository that provides access to Queen's research output. Every effort has been made to ensure that content in the Research Portal does not infringe any person's rights, or applicable UK laws. If you discover content in the Research Portal that you believe breaches copyright or violates any law, please contact openaccess@qub.ac.uk. 
(C) Tori Holmes, 2017. Final author version. The definitive, peer reviewed and edited version of this article is published in Journal of Urban Cultural Studies 4:1+2, pp. 63-85, doi:

10.1386/jucs.4.1-2.63_1

Giving visibility to urban change in Rio de Janeiro through digital audio-visual culture:

A Brazilian webdocumentary project and its circulation

Tori Holmes, Queen's University Belfast

\begin{abstract}
This article discusses the crowdfunded Brazilian webdocumentary project Domínio Público (produced by the audio-visual collective Paêbirú Realizações Cultivadas), which portrays urban transformations in Rio de Janeiro in the run-up to the city's hosting of the 2014 FIFA World Cup and the 2016 Olympic Games, with a particular focus on the impact in the city's favelas. It argues that Domínio Público can be understood as a snapshot of a key moment in the recent history of Rio de Janeiro and of Brazil, which intertwines Rio's urban transformations with digital audio-visual culture, fundamental for the circulation and visibility of these processes in Brazil and abroad, as well as with national political processes and crises which would go on to take unforeseen directions and proportions after the film's release. The article shows how circulation and visibility were embedded in the project from the outset, and became an intrinsic part of its critical narrative on urban transformations.
\end{abstract}

\title{
Keywords
}

Brazil

Rio de Janeiro

webdocumentary

circulation

urban change 
favelas

visibility

mega-events

On 11 June 2014, on the eve of the 2014 FIFA World Cup in Brazil, the feature-length version of crowdfunded Brazilian webdocumentary ${ }^{1}$ Domínio Público (Public Domain) (Mota, Vidal and Ligeiro, a.k.a. Paêbirú Realizações Cultivadas, 2014) had its premiere at an outdoor screening next to the Arcos da Lapa viaduct in downtown Rio de Janeiro. The film's 2042 crowdfunders, who had supported the collectively-made film to the tune of $106,221^{2}$ Brazilian reais (equivalent to just over $£ 32,000$ at the time) during a 2012 campaign on the Brazilian crowdfunding website Catarse, received rewards ranging from inclusion in the credits to links for early or extra downloads, a t-shirt, a poster and original artwork. Three days later, the webdocumentary was released first on YouTube, ${ }^{3}$ and then on Vimeo, ${ }^{4}$ with the exhortation to share it as widely as possible, without restrictions: 'Baixem, copiem, e exibam!' ('Download it, copy it, screen it!') (Paêbirú Realizações Cultivadas n.d.). ${ }^{5}$ By early July, the filmmakers had made available subtitles in English and Spanish; French, Italian and Portuguese later followed, the latter with the goal of making the film as accessible as possible. Since then, screenings of the feature-length version of Domínio Público have been organized in Rio, elsewhere in Brazil, and in other countries including the United Kingdom, Austria and Switzerland. It has also been watched close to 100,000 times on YouTube/Vimeo. ${ }^{6}$ More than just a film, this is a self-proclaimed 'documentary project' (Coffmann 2014: 112) encompassing a variety of audio-visual materials, profiles and content on social media platforms, a designated hashtag (\#DomínioPúblico) and a circulation strategy straddling digital and audio-visual culture. As this article will show, the related concepts of circulation and visibility were embedded in the project from the outset and became part of its 
critical narrative on urban transformations.

Developed over three years beginning in 2011, in the period leading up to Rio's hosting of part of the 2014 World Cup, and the 2016 Olympic Games, Domínio Público set out to investigate 'as transformações no Rio de Janeiro por conta dos megaeventos: UPPs nas favelas, remoções forçadas, privatizações de espaços públicos e revoltas populares' ('the transformations in Rio de Janeiro due to the mega-events: UPPs [Pacifying Police Units] in favelas, forced removals, privatization of public spaces and popular revolts') (Paêbirú Realizações Cultivadas n.d.). It was originally intended as a short film, but turned into a feature-length documentary as the filmmakers realized the full extent of their subject matter. The production and release of the feature-length version was also delayed due to the largescale street protests that took place in Rio de Janeiro and many other Brazilian cities in June 2013, which were incorporated into the project. The resulting film combines interviews (with mainly Brazilian activists, politicians, academics, journalists, favela residents and the police, although there is also an interview with US-based geographer David Harvey), footage of events, meetings, protests and locations relating to the thematic focus, and images and footage from other sources, including the Internet.

This article argues that Domínio Público can be understood as a snapshot of a key moment in the recent history of Rio de Janeiro and of Brazil, ${ }^{7}$ which is still playing itself out. This is a snapshot which intertwines Rio's urban transformations with digital audio-visual culture, fundamental for the circulation and visibility of these processes in Brazil and abroad, as well as with national political processes and crises which would go on to take unforeseen directions and proportions after the film’s release. Domínio Público achieved significant circulation and visibility thanks to fortuitous timing and hard work, but it also offered a critical reflection on how circulation and visibility, associated with digital audio-visual culture, have been part of the process of urban transformations in Rio. The flexible and 
responsive nature of the project, and its ability to sustain an 'afterlife' (Harbord 2002), are evident in the ongoing use of its Facebook page, well into 2016, to post and repost content on a whole range of issues related to its thematic focus, both local and national.

Based on episodic fieldwork (Whyte 2013) undertaken both on the Internet and in situ in Rio de Janeiro since 2013, this digital ethnography (Pink et al. 2015) draws on interviews with one of Domínio Público's filmmakers undertaken via Skype and in person, the analysis of audio-visual and digital material produced by the project, participant observation at a screening of the film in 2015, and analysis of digital content about the project from other sources. It begins with a brief discussion of urban transformations in Rio and the digital/audio-visual context which gave rise to Domínio Público. It then introduces the concepts of visibility and circulation, before discussing how they manifest themselves in selected aspects of the Domínio Público project, namely its crowdfunding campaign, screenings, and Facebook page/hashtag.

\section{Urban transformations in Rio de Janeiro}

Rio's history has been punctuated by moments of urban transformation - sometimes triggered or inspired by outside influences or forces - and there is a rich historical scholarship on key moments of change, such as the period when the city served as seat of the Portuguese court from 1808-21 and transitioned rapidly from slave port to imperial capital (Schultz 2001; Wilcken 2005), and the Pereira Passos reforms of 1903-06, which sought to make Rio into a more 'European' city (Needell 1984, 1987, 2010; Meade 1996). In addition, scholars have charted cultural responses to urban change in late nineteenth and early twentieth century Rio de Janeiro (Acerbi 2014; Beal 2012; Conde 2005, 2006; Leu 2014), and produced volumes tracing Rio's development and representation over time, through different cultural 
forms, which reinforce the importance of understanding contemporary transformations in historical context (Carvalho 2014; Jaguaribe 2014).

The emergence of the Rio's now-famous favelas at the end of the nineteenth century and their development since then are well-documented (Perlman 2010; Alvito and Zaluar 1998; Valladares 2005), and there have also been studies focusing specifically on removals of the urban poor in the 1920s and 1960s (Fischer 2011; Mattos 2013; Brum 2013; Valladares 1978). As the introduction to a recent book on contemporary Rio argues, contemporary urban transformations dialogue with those of the past, which 'pervade the repertoire through which Rio has been presented to the world, including as an Olympic city' (Carvalho et al. 2016: 24). For Beatriz Jaguaribe and Scott Salmon, the Rio de Janeiro authorities have used the Olympics

as the catalyst for a process of urban reinvention grounded in the production and (re)appropriation of urban space - a process that is simultaneously material and symbolic. It has focused on strategically significant terrains, emblematic spaces that are critical to the city's rebirth in the global imaginary. (2016: 36)

Urban transformations thus play out on multiple planes, which can be revealed through the analysis of a project like Domínio Público, which traverses, and connects, the digital and the place-based (in this case, the urban).

As geographers Matthew Richmond and Jeff Garmany (2016) have argued, interpretations of contemporary urban transformations in Rio have tended to fall into two broad camps. The first, a 'post-Third-World city narrative', has been propagated by the government officials and bodies leading the transformation, 'with a degree of public 
resonance', and the second, 'a city-of-exception thesis', has been advanced by academics and 'has also influenced the tactics and rhetoric of oppositional social movements' (Richmond and Garmany 2016: 623). As the authors explain,

$[\mathrm{t}]$ he former argues that Rio is undergoing a period of inclusive growth and integration (led by mega-event initiatives and urban renewal), while the latter contends that urban officials are harnessing mega-events to push forward socially unjust policies that further marginalize Rio's poor and working-class residents. (Richmond and Garmany 2016: 622)

Domínio Público can be understood as sympathetic to the 'city-as-exception' thesis, and indeed it includes an interview with the original author of that thesis, Rio-based urban planning scholar Carlos Vainer. However, as the list of interviewees mentioned earlier suggests, the film presents a plurality of voices in its portrayal of urban transformations. Richmond and Garmany point out that recent urban transformations in Rio 'have appeared at a particular historical conjuncture' (2016: 623), at both national and municipal level. Although the narrative has more recently shifted to one of crisis, over the past ten to fifteen years Brazil has been seen as a country on a positive economic and political trajectory, with a heightened international profile (Dauvergne and Farias 2012; Almeida et al. 2014; Sotero 2010). At the same time, Rio has been promoted both domestically and internationally 'as a creative city and international cultural hub [...] a focal point for international attention' (Marsh 2016: 3028). As Carvalho notes, the successes in securing mega-event host status not once but twice recognized both contexts of emergence: 
[i]n 2007, winning the hosting rights to the 2014 World Cup signalled Brazil's emergence on the global stage, validated by a relatively successful weathering of the 2007-08 financial crisis. In October 2009, Rio de Janeiro's election as the first South American host to the Olympics meant that the city's time had also come. (2016: 23)

As part of this raised profile, Brazilian 'cultural manifestations' (Frangella 2013) have gained greater presence and visibility outside of Brazil since the early 2000s. Although some familiar and long-held stereotypes about Brazil have persisted in these manifestations, there has also been a shift, with elements and references to urban Brazil, and specifically to Rio's favelas, occupying an increasingly prominent position (Leu 2007; Frangella 2013). Interest in Rio was also boosted in the run-up to the World Cup and Olympics, as the international media increased their presence in the city, with some observers pointing to a greater sensitivity to the complexity of Rio's favelas in reporting during this period (Williamson 2016; Bailey et al. 2017).

Media and cultural interest has been accompanied by academic interest. In recent years there has been a growth in English-language publications on mega-events and urban transformations in Rio, both from academics with an existing trajectory of research on Brazil, and from those with a disciplinary or global interest in the topic, mainly in social science disciplines or fields. Articles have been published on urban regeneration schemes (Sánchez and Broudehoux 2013; Gaffney 2010, 2016), the UPP favela pacification scheme (Prouse 2012; Freeman 2014; Oosterbaan and Wijk 2015; Penglase 2016), and removals/evictions in urban periphery areas (Freeman and Burgos 2016; Donaghy 2015; Barre 2016; Silvestre and Oliveira 2012). The 2013 protests, in Rio and other cities, have also attracted attention (Conde and Jazeel 2013; Sampaio 2014; Saad-Filho 2013; Holston 2014; Friendly 2017; 
Sotero 2014). In this article, I seek to show that the interdisciplinary analysis of digital cultural works such as Domínio Público, which have not yet figured strongly in this literature, can offer valuable insights into processes of urban transformation and responses to them.

\section{Visibility and circulation}

Whilst Domínio Público was not made by filmmakers from the urban periphery, ${ }^{8}$ its portrayal of the impact of urban transformations in Rio has a clear emphasis on how the city's favelas and their residents have been affected by the changes, and gives prominence to the voice of favela residents and interviewees sympathetic to them. The project also developed partnerships with favela-based groups both during its production and for the purposes of screenings. It can be understood as an intervention in the politics of visibility surrounding Rio de Janeiro and its favelas, and a project which draws attention to this politics.

John B. Thompson has put forward the idea of a 'new form of visibility' (2005: 32), a mediated form of visibility resulting from the rising importance of communications media. As he explains, physical and temporal co-presence with a person, an action, or an event is no longer a prerequisite for visibility (Thompson 2005: 35). For Thompson, the emergence of digital media

has amplified the significance of the new forms of visibility created by the media and at the same time rendered them more complex. They have greatly increased the flow of audio-visual content into the networks of communication and enabled a much wider range of individuals to create and disseminate this content. (2005: 37-38) 
At the same time, political elites have found it harder and harder to control the circulation of images (Thompson 2005: 37). Thompson argues that 'in this modern age of mediated visibility, the struggle to be seen and heard, and the struggle to make others see and hear, has become an inseparable part of the social and political struggles of our time' (Thompson 2005: 49). As he goes on, 'The visibility of actions and events [...] have become an inseparable part of the unfolding of events themselves' (Thompson 2005: 49).

Research has highlighted the central role played by the media in visibility in Brazil. For Jaguaribe and Lissovsky, since the 1970s, 'Brazil has become a nation characterized by a strong audio-visual culture' (2009: 204), where television has a particularly important function in channelling national visibility. The 2010 census found that television sets are present in more than 95 per cent of Brazilian homes (iG São Paulo 2012). Alongside television, film and video have been important vehicles for increasing the audio-visual representation, and self-representation, of the urban periphery and its residents. This has taken place on different scales. The global success of the film Cidade de Deus (City of God) (Meirelles and Lund, 2002), had knock-on effects for increases in favela tourism. As Bianca Freire-Medeiros, the author of a study on this topic, has observed, entrenched stigmas and stereotypes regarding favelas do not evaporate with their new global projection and circulation, but a 'new politics of visibility are definitely at play, for good or bad' (2009: 580). Similarly, Jaguaribe and Lissovsky (2009: 207) write of 'a new agenda of the visibility of the excluded', in reference to so-called 'visual inclusion' projects which train favela residents in photography.

Beginning in the 1980 s with video production by non-governmental organizations and social movements, grassroots audio-visual production has constituted an important arena for greater visibility of the urban periphery and other marginalized groups in Brazil. Although this movement weakened in the 1990s, it has been experiencing a resurgence since the second 
half of the 2000s (Sotomaior 2015; Santoro 2014). For Gustavo Souza, the contemporary audio-visual production of the Brazilian urban periphery points to the existence of 'a dispute around what deserves visibility' (2012: 107), and Daniela Zanetti (2010) has highlighted the important role of specialist film festivals in giving visibility to this type of production.

In approaching the issue of visibility in Domínio Público, both its audio-visual and digital aspects must be taken into consideration. Whilst audio-visual culture has been central to Brazil since the 1970s, digital culture has also become an important vehicle of visibility in recent years, and the two are now intertwined. As Bryan McCann has argued, the rise in access to digital technologies is one of the six trends that have most changed Brazil since the 1980s (2008: 10). Whilst it does not yet have the same extensive reach as television, and many access inequalities persist, 51 per cent of Brazilian homes now have an Internet connection (CETIC.br 2016). Levels of social media use are high in the country (Horst 2011; Olinto and Fragoso 2011) and recent research has drawn attention specifically to the role of the Internet in facilitating a greater, and more varied, visibility of the urban periphery, and the role of urban periphery residents in this process (Gomes da Cunha 2007; Jaguaribe 2014; Holmes 2016; Custódio 2014; Davis 2015; Millington and Darnell 2014).

Digital culture is thus a central component of the contemporary 'field of peripheral audio-visual production' (Yúdice 2013) in Brazil, out of which Domínio Público arose. This is a sphere which challenges and reformulates the dominant field of audio-visual production, and is composed of a 'new generation of filmmakers who adopt a post-industry practice', the 'audio-visual divisions of community organizations in favelas', 'youth collectives', and 'other kinds of peripheral audio-visual organization' (Yúdice 2013: 240). Rather than the narrative feature-length film, peripheral audio-visual production favours other formats including 'collaborative production, documentaries, shorts, activist video' (Yúdice 2013: 239). Although some authors argue that the impact of digital technologies in this sphere 
should not be overstated, since many of the practices associated with audio-visual production remain the same (Santoro 2014; Sotomaior 2015), digital technologies and social media have opened up different possibilities for the production and circulation of audio-visual work. Digital platforms are now commonly used to disseminate work, at the same time as physical circuits persist (Yúdice 2013: 239). As suggested by Craig Hight in his work on digital documentary (2008), the relationship between digital and audio-visual culture can here be understood as a two-way process of 'remediation' (Bolter and Grusin 2000), in which digital culture refashions audio-visual culture and vice versa.

The contemporary intertwining of audio-visual and digital culture in peripheral audiovisual production itself gained visibility during the 2013 protests in Brazil (Rigby 2013; Holston 2014; Spuldar 2013). In these protests, 'protestors of all classes came together around many common issues' (Holston 2014: 890), including urban mobility, public security, public services, and corruption. Alongside these shared national causes, protests in individual cities were a manifestation of concerns about local policies implemented by municipal and state governments (Sotero 2014: 7), with issues associated with urban transformations figuring prominently in the protests in Rio (Rekow 2015; Gutterres 2014; McCann 2014). Nationwide, social media and digital technologies were widely used to mobilize, document and reflect on the protests, by participants as well as the mainstream media. Amongst the proliferation of digital content produced about the protests, digital video was a particularly important strand. Perhaps the best-known source of such content, and the one that has attracted the most scholarly attention so far, was the Mídia Ninja collective (Stalcup 2016; Gregory 2015, d'Andréa and Ziller 2015, Bittencourt 2014; Davis 2016), which produced live streaming of the demonstrations via smartphones and twitcasting technology; its footage even appeared on national television.

For Eduardo Escorel (2014), the live digital coverage of the protests by both Mídia 
Ninja and mainstream journalists 'reafirmaram a obrigação de redefinir o cinema documentário, vinculado à atualidade' ('reaffirmed the obligation to redefine documentary cinema, linked to current affairs'). Indeed, according to Fausto Mota of Paêbirú Realizações Cultivadas, the collective behind Domínio Público, there were two different audio-visual responses to the protests of 2013, one being 'midiativismo' (media-activism), like that practised by Mídia Ninja, and the other being 'a proposta de fazer filme, fazer documentário, e criar linguagem a partir disso' ('the proposal to make films, make documentaries, create a language from that'), which Domínio Público pursued (Mota, 12 August 2015, interview). As Paêbirú wrote in an update to their crowdfunders on Catarse in December 2013, regarding the delay in production occasioned by the June protests, 'não podíamos parar por ali.

Participamos desse momento histórico e esses acontecimentos também entrarão no filme’ ('we could not stop there. We participated in this historic moment and these events will also be part of the film') (Paêbiru Realizações Cultivadas LTDA EPP 2013).

Several documentary films have now been released about the protests, ${ }^{9}$ which have made 'a relatively quick impression in contemporary Brazilian filmmaking' (Solomon 2016). Aside from their value in documenting and reflecting on the events of June 2013, one of the most interesting formal features of these films is the way that they have repurposed the extensive digital and audio-visual coverage of the events in different ways. Whilst not exclusively about the 2013 protests, Domínio Público can be included in this category. The protests constituted a key moment in the expression of opposition to urban transformations in Rio, and this had a direct impact on the film's production process. Drawing on Thompson's ideas about the inseparability of actions and events and their visibility, I argue here that as an audio-visual representation of urban transformation, Domínio Público is itself not only a valuable record of a socio-historical moment, but part of that moment itself. Visibility is an important dimension of urban transformation, and as my analysis will show, visibility is 
explicitly foregrounded in Domínio Público. However, in parallel, and often in tandem, circulation also figures strongly in the project, and will be briefly introduced here before turning to the analysis.

Thompson mentions circulation in his discussion of visibility, showing the link between the two. Circulation can be understood as a route to visibility, and like visibility, the term is used in relation to both urban contexts and audio-visual/digital ones. Indeed, the term has gained currency in both urban studies and communication/media studies, and Boutros and Straw (2010) call for work that 'locate(s) circulation within the concrete spaces of cities and include(s) an account of a cultural artefact's embeddedness in specific spaces and times' (Boutros and Straw 2010: 9). They note that the concept of circulation 'inevitably evokes both space and time' (Boutros and Straw 2010: 11), both of which will be relevant in the discussion of Domínio Público.

Circulation has also become increasingly prominent in film studies, with authors such as Dina Iordonova arguing that digital technologies have enabled a process of disintermediation, whereby the same parties are responsible for audio-visual production and dissemination, leading to the increasing viability of the term circulation, over distribution (2012: 6). Although the study of film circulation can be compelling in its own right (Lobato 2012), Brian T. Edwards (2011) proposes that in a digital culture, attention to the circulation - or motion - of cultural works should go hand in hand with the study of their content, or meaning. For Edwards, digital culture requires a new 'reading strategy that puts circulation at the focal center' (2016: 35). This dual reading strategy is ideal for a work like Domínio Público, and I will employ it here. As I will show in the following two sections through a discussion of the project's crowdfunding campaign and materials, Domínio Público positioned circulation and visibility at the heart of its content and its approach to dissemination. If it can be assumed that in general, filmmakers want their films to be seen (to 
be visible) and to circulate, what distinguishes Domínio Público is that visibility and circulation are an intrinsic part of its critical narrative on urban transformations.

\section{Domínio Público as an Internet phenomenon}

Whilst Domínio Público's collaborative approach to funding is clearly one dependent on platforms and practices associated with digital culture, it can also be understood, in Brazil and elsewhere, as a response to dissatisfaction with the mainstream cultural and audio-visual funding milieu, as well as the reduced availability of resources (Sørensen 2012). In Brazil, crowdfunding has become a viable option for funding low-budget, alternative film projects (Valiati and Tietzmann 2015). Domínio Público's filmmakers were inspired by the success of crowdfunded documentary Belo Monte (d'Elia, 2012), about a dam in Brazil's Amazon region, which managed to secure contributions from 3429 supporters on Brazilian crowdfunding platform Catarse (Valiati and Tietzmann 2015: 63). Domínio Público's own campaign, launched on Catarse in mid-September 2012, argued that its controversial subject matter made securing funding from traditional sources difficult:

Os meios de financiamento no Brasil são oriundos de leis de incentivo/editas [sic] que envolvem o governo ou grandes empresas, que jamais apoiariam projetos como o nosso. (The funding streams in Brazil come from cultural incentive laws/public funding calls that involve the government or big companies, which would never support projects like ours.) (Paêbiru Realizações Cultivadas LTDA EPP n.d.)

In crowdfunding, a film's potential audience is not just vital for funding the film, but also for disseminating the project and mobilizing other potential funders. Under the Catarse model 
funds are only released if the target is met; if not, funds return to contributors. The project's success, and indeed its feasibility, depended on achieving visibility.

The minimum contribution was ten Brazilian reais (giving the right to have one's name included in the credits) and the maximum contribution was 5000 reais or over (entitling one to all the possible rewards, ranging from inclusion in the credits to links for early or extra downloads, a t-shirt, a poster and original artwork). A video totalling seventeen minutes and 45 seconds was made available on the Vimeo platform, and in early October subtitled versions in English, French and Spanish were also released. The target for the crowdfunding campaign was 90,000 Brazilian reais and the deadline was set as 16 November 2012.

Efforts in support of Domínio Público's crowdfunding campaign involved digital culture, but also audio-visual culture - in other words, physical screenings - and physical circulation around the city. During this period the short was screened at least five times and at least three other short videos were released, including one with a call for support from the Rio musician BNegão, which will be discussed later. In late October, the filmmakers organized a fundraising party with live music, charging twenty reais, and in early November, when the film was screened at the Circo Voador venue in downtown Rio as part of an arts festival, they set up a stall at which people could contribute in cash, by card or by bank transfer.

There was also a significant social media effort associated with the crowdfunding campaign. Multiple messages and reminders were posted on the project's Facebook and Twitter profiles, generating coverage and calls for support on other profiles and blogs/websites. There were several appeals from filmmakers as the deadline drew near, including one which asked friends and allies to share the video, to copy and paste text on their Facebook walls: 'COMPARTILHEM O VÍDEO!!! COPIEM E COLEM ESSA MENSAGEM NOS SEUS MURAIS!!!’ ('SHARE THE VIDEO!!! COPY AND PASTE 
THIS MESSAGE ON YOUR WALLS!!!'). As Fausto later told me, Facebook was fundamental for the visibility and circulation of the crowdfunding video: 'ele explodiu pelo Facebook' ('it exploded on Facebook') (Mota, 8 September 2014, interview).

Domínio Público's crowdfunding video attracted significant levels of interest both in Brazil and abroad. As Fausto told me, the short film 'virou um fenômeno na Internet, a gente perdeu o controle' ('became a phenomenon on the Internet, we lost control') (Mota, 8 September 2014, interview). In their analysis of cinema crowdfunding in Brazil, Valiati and Tietzmann (2015: 64) note that the most successful projects tend to share two characteristics: the information they provide about the project is well structured, and they make a significant effort to keep supporters up to date. The authors also note that good timing is crucial for success, in terms of the coherence between a crowdfunding campaign and the wider social context. This is something Fausto emphasized to me about Domínio Público, saying 'o filme foi lançado na hora certa, no momento certo, pouca gente estava falando sobre aquilo' ('the film was launched at the right time, at the right moment, hardly anyone was talking about that') (Mota, 12 August 2015, interview). Another factor in Domínio Público's success, again echoing broader global patterns (Borst et al. 2017), appears to have been its ability to attract funders beyond the filmmakers' friends and family. Thanks to capturing a certain moment in the urban transformation process, and offering people a way to contribute to the visibility and circulation of a critical perspective through their funding of the film, Domínio Público mobilized people in a collective and collaborative effort and in turn guaranteed its own visibility and circulation.

Quantitative data helps to illustrate this. According to statistics shown to me by the filmmakers, captured in May 2015, the Vimeo page for the crowdfunding video with English subtitles was loaded more than one million times, by users in more than 150 countries, and played over 225,000 times. In Brazil alone, it was loaded over 820,000 times and played just 
under 185,000 times. The top five countries in the rankings were Brazil, the United States, Portugal, Germany and the United Kingdom. In March 2017, this figure was relatively unchanged, with statistics publicly available on Vimeo showing it had been played 230,000 times, ${ }^{10}$ alongside 181,000 plays of the version without subtitles. ${ }^{11}$ The versions with French and Spanish subtitles add up to just over 50,000 views together. ${ }^{12}$ The short is also available on YouTube, with English subtitles, where it showed just over 60,000 views in March $2017 . .^{13}$

As mentioned, the crowdfunding campaign was a success and Domínio Público surpassed its funding target by 16 per cent. As well as financial support, the filmmakers also received offers of other types of help such as equipment, studio space, and footage, which proved crucial to this collaborative project. The project's noteworthy crowdfunding campaign itself became a driver of visibility for the project, with Domínio Público ranked fourth amongst Catarse crowdfunding projects in the 'cinema and video' category, for the amount of money raised, in the period 2011-13 (Valiati and Tietzmann 2015: 63). In September 2014, it was screened as part of the CoCidade festival in São Paulo, focusing on crowdfunding and collaborative projects in cities, which ran for the first time that year. Overall, the visibility and circulation of Domínio Público’s crowdfunding campaign achieved reach and results. The focus will now shift to how the visibility and circulation are embedded in the content of the project, which interweaves the digital/audio-visual and the urban in its discussion of Rio's transformations.

\section{Foregrounding urban and digital visibility}

The theme of visibility forms part of the content of the crowdfunding materials, where it is presented as a justification for the film and its urgency, and a reason to support it. From the start, the project's crowdfunding video foregrounds the risks or constraints associated with 
public criticism of urban transformations and their impact in favelas, but also the need for such criticism. ${ }^{14}$ Four of the film's interviewees (who also feature later in the video) appear in sequence, each asking for the camera to be switched off or for something to be cut out, or referring to things that cannot be said on camera. There is also footage of an armed policeman, in a favela setting, asking the filmmaker behind the camera to turn off the camera. Asked about this sequence in an interview with investigative journalism website Pública, Fausto Mota said, 'As pessoas preferem não tocar em certos assuntos polêmicos com medo de ter sua integridade física ameaçada, como já cansamos de ver tanto no Rio quanto no resto do Brasil e do mundo' ('People prefer not to talk about certain controversial subjects due to fear of putting their physical safety at risk, as we are tired of seeing both in Rio and elsewhere in Brazil and the world') (Dip 2012).

In the crowdfunding video, it is Raoni Vidal, one of the directors, who makes the case for facing up to these risks. Speaking to the camera, he says:

A Copa do Mundo e as Olimpíadas estão chegando no Brasil, e há pouca informação nos meios de comunicação sobre o que realmente está acontecendo. Bilhões dos nossos cofres públicos estão sendo investidos no país e não sabemos para onde está indo todo esse dinheiro. Por isso, decidimos fazer este filme por conta própria e vimos que há muita sujeira a ser investigada. $\mathrm{O}$ mundo inteiro precisa saber das injustiças cometidas contra o povo brasileiro. (The World Cup and the Olympics are coming to Brazil, and there is little information in the media about what is really happening. Billions from our public coffers are being invested in the country and we don't know where all this money is going. For this reason, we decided to make this film on our own and we saw that there is a lot of dirt to be investigated. The whole 
world needs to know about the injustices committed against the Brazilian people.)

The interview response from Fausto Mota quoted above and this appeal from Vidal, both of which link domestic and international contexts of visibility, reinforce the high stakes associated with urban transformations, in the filmmakers' view, and stress the impetus that exists to document what is happening in Rio, the raison d'être of Domínio Público.

Vidal's appeal to potential crowdfunders is followed by the film's title frame, which shows the word 'Dominio' (without an accent) in white capital letters on a medium-blue background, in an inversion of the normal colour scheme of the UPP pacification programme, and the word 'Público' in black hand-written letters below on a white background, recalling graffiti. This title frame is repeated in the feature-length version of the film, this time following footage of a graffiti artist walking up to a sign saying only 'Domínio' (now with an accent), located at the side of a road with a favela visible in the background, and adding 'Público' by hand using spray paint. In the feature-length version, we then see a uniformed policeman operating a clapper board whilst a voice says 'Domínio Público, take um' ('Domínio Público, take one').

As already mentioned, the digital audio-visual material produced by Domínio Público is freely available online, and is often accompanied by text explicitly encouraging its free and wide use and circulation. The title refers to freedom of access, without restriction or copyright, but its attachment to a film about urban transformations points to how the same philosophy of openness and visibility informs the approach to the subject matter. The connection between the digital and urban contexts also recurs in text accompanying a promotional short video for the film, ${ }^{15}$ used in the crowdsourcing effort, which featured the singer BNegão, himself known for his support of copyleft approaches to cultural production 
(Silva and Paz 2012). The text in question playfully links the removals associated with the mega-events in Rio, part of Domínio Público's subject matter, to the censorship and removal of contentious content online, a potential hazard for a project like Domínio Público: 'Esse filme investiga, denuncia e pode ser removido. Assista já! Se não removerem o vídeo, podem remover você!' ('This film investigates, denounces, and could be removed. Watch it now! If they don't remove the video, they might remove you!'). In March 2017, this 'extra' video had 22,900 views on YouTube, further evidence of the reach of the Domínio Público project, in all its manifestations.

Both the opening sequence of the crowdfunding video and the title of the project show that Domínio Público seeks to make visible, and promote the unrestricted circulation of, narratives about urban transformations in Rio which are absent from the public domain, whether through neglect or (self-)censorship. As well as affording visibility to issues relating to urban transformations, the project foregrounds the process of making them visible through audio-visual production and the media. The film itself, situated at the nexus of urban transformations and digital audio-visual culture, can thus be considered a meditation on visibility in relation to both these areas, which it explicitly links.

\section{'Obligatory viewing for those who want to understand where we are'}

Visibility often intertwines with circulation in Domínio Público, showing that these concepts are closely interrelated. Circulation is part of the project's approach to visibility, and is embedded into the project, through the different channels or approaches employed. In line with its origins in the 'field of peripheral audio-visual production' (Yúdice 2013), the filmmakers sought to create 'um caminho alternativo' ('an alternative path') for the film (Mota, 8 September 2014, interview), not opting for the established route for documentary distribution, the festival circuit (although the film has been screened at many 'mostras', as 
smaller curated, often thematic, film series or events are known in the Brazilian audio-visual scene). The aim, foregrounded in the project - and its name - from its inception, was to promote the film's wide and free circulation through as many channels as possible, without imposing any kind of hierarchy. As Fausto emphasized, 'o filme foi feito, pensado para ser exibido à princípio na Internet, na rua, em cineclube, em faculdade, em favela' ('the film was made, conceived to be shown initially on the Internet, in the street, at cineclubs, at universities, in favelas') (Mota, 12 August 2015, interview). The project also incorporated Paêbirú's existing Cine Ataque method, an urban intervention involving the screening of films in open-air public spaces in the city, with the aim of making audio-visual production visible to audiences.

Whilst Domínio Público is being referred to as a 'webdocumentary' (Nash 2012) in this article, I use the term with the recognition that the film, although explicitly made for viewing on the Internet, has also been accessed and viewed in other settings. Nonetheless, the prefix web- is appropriate because of the multiple ways in which Domínio Público's production and circulation are pervaded and influenced by digital technologies. Fausto's list of potential screening venues summarizes well the plurality of spaces for audio-visual exhibition and debate that make up the contemporary peripheral audio-visual circuit in Brazil, and the ongoing centrality of physical screenings, alongside digital circulation.

Footage of screenings appears in the Domínio Público crowdfunding video, and can be understood as part of the package being 'sold' to potential crowdfunders. This demonstrated not only that circulation was central to the project, but also that the proposed circulation of the finished product would not be restricted to elite audio-visual circuits, but would also reach the areas affected by urban transformations. On three occasions in the short, talking head interview footage is followed by images of that same footage being screened, the first time in an unidentified indoor cineclub setting, the second in Cinelândia square in 
downtown Rio de Janeiro, and the third time on a makeshift screen, outdoors, in what appears to be an urban periphery setting. This shows the video's audience, potential funders of the project, that the filmmakers are making the audio-visual material available to people affected by urban transformations, implying dialogue and accountability. Just as they moved around the city in making the film, they were keen to show their material doing the same.

If one of the striking things about the 2012 crowdfunding video was its wide reach and the visibility it achieved online, physical screenings have had more prominence in the circulation of the feature-length version of Domínio Público. In some ways this is not surprising - crowdfunding is, after all, an approach enabled by the affordances of digital platforms even if crowdfunded projects often rely on existing contacts and acquaintances, as already noted (Borst et al 2017). The Domínio Público crowdfunding video was explicitly made to be shared and viewed online. The feature-length film was the outcome or culmination of the crowdfunding and production process, an actual 'film', and although a webdocumentary, it was firmly rooted in an audio-visual culture that values physical screenings.

As mentioned in the introduction, the release of the full film on YouTube and Vimeo in June 2014 was accompanied by an exhortation to watch the film online, but also to download it and screen it; this was helped by the film being put on Torrent. The popularity of physical screenings of the film may also be, in part, due to its length (it is about one and a half hours long) and to the desire to make the film as widely available as possible, including to residents of favelas. As Fausto pointed out (Mota, 8 September 2014, interview), there are downsides to the Internet as a distribution channel. Watching a feature-length film on a computer or handheld screen can certainly be awkward, but there are also inequalities in Internet access that might make it harder for certain social groups to do this, such as favela residents. The filmmakers themselves had difficulty when uploading the finished film to 
YouTube in June 2014, due to its size.

Domínio Público has been shown at cineclubs (at universities, in favelas, in occupations, in cultural venues, in Rio itself and in other Brazilian cities), as part of thematic 'mostras' (e.g. on crowdfunded projects, on the link between music and political activism, on political cinema), and on the Curta! satellite/cable television channel in Brazil. Beyond Brazil, it has also been screened in London, Buenos Aires, Toulouse, Graz, Vienna and Zurich. The events in London and Swiss/Austrian cities were part of an event called Manifest:Action organized by Braziliarty, a London-based cultural events production company focused on Brazil, in partnership with Amnesty International. The event first took place in London during the World Cup of 2014, combining a photo exhibition, film screenings, and debates with a human rights focus. Both the short and long versions of the film were screened over the course of several weeks, and it was billed as a film 'on the hottest topic of the year' (Braziliarty 2014). Based on its success in London, the event was then taken to Austria and Switzerland in October 2014 in partnership with local Amnesty branches, again involving screenings of Domínio Público. Here we see the film being adopted as part of a campaign for awareness-raising and mobilization about human rights issues. This complements the circulation promoted by the filmmakers themselves, but is very much in line with their intentions for the film.

As Mollerup and Gaber have pointed out in their work on street screenings in Egypt, film 'screenings entail much more than people looking at a screen' (2015: 2908). As they write, "The "same" image could become something totally different in interaction with different audiences, surroundings, and moments of its screening' (Mollerup and Gaber 2015: 2917). This points again to the importance of timing and context for the circulation of audiovisual work, and specifically of Domínio Público, which has been a theme throughout this article. If Domínio Público had an urgency on its delayed release in June 2014, the month of 
the World Cup, it has continued to be relevant since then. The filmmakers themselves commented on this in a message posted on Facebook in September 2014, saying:

Entretanto, mesmo após o lançamento do filme em 12 de junho, véspera do início da Copa do Mundo no Brasil, nossa missão não acabou. O projeto está vivo e sendo apresentado e debatido em instituições culturais, artísticas e de ensino do Rio e de todo o Brasil. (However, even after the launch of the film on 12 June, the eve of the start of the World Cup in Brazil, our mission is not finished. The project is alive and being screened and debated in cultural, artistic and educational institutions in Rio and all over Brazil.)

In 2015, I experienced for myself how the meaning of a film can vary over time, when I attended a screening of Domínio Público in premises managed by a municipal councillor for a left-wing political party in the Lapa neighbourhood. The cineclub held in the ground floor space, with windows open to the street which passes directly outside, is a regular event and shows films on social themes followed by debates; posters for previous sessions and other events held in the space adorned its exposed brick walls. On that occasion, Domínio Público had been selected for a thematic session on removals in favelas. The panel for the debate was composed of one of Domínio Público's directors, plus an academic, a community activist from the Vila Autódromo favela in western Rio de Janeiro, well known for its resistance to eviction by the city administration, and a representative of the Comitê Popular da Copa e Olimpíadas, a civil society support group. Both the film and the debate were to be streamed live and as I waited for the event to begin, sitting on one of the white plastic chairs arranged in rows in the middle of the room, I watched the councillor's press officer setting up the laptop and projector and preparing digital content for later posting on 
social media, as well as copying and pasting an image from the Facebook 'event' to project on the screen. Although it was a physical screening of the film, digital culture was never far away.

It was my first opportunity to attend a screening of the film, which I had previously only watched on the Internet, on its release in 2014. The film itself was not quite the same, however, since this screening used a new copy released in 2015 to correct some quality issues in the 2014 version. Having previously lived in Rio de Janeiro, I had an interest in the changes that the city had been undergoing since its announcement as the host city for the Olympics in October 2009, beyond my research interest. Watching Domínio Público in situ in Rio de Janeiro, at the end of a week of fieldwork on my first trip back to the city since those protests, provoked a different kind of recognition and proximity to the film and to the city than that I had experienced when watching it online and at a distance. Walking around Rio, I had revisited familiar locations shown in the footage of the 2013 protests, towards the end of the film, realizing that two years on from the protests, and three years after my departure, the city was not the same city. As well as the physical transformations (such as the tracks for the VLT light rail system being constructed down the middle of Avenida Rio Branco at the time), it also bore the marks, both physical and symbolic, of the mass occupation of urban space by the protesters of June 2013, whose memory was captured in films like Domínio Público.

A similar sentiment of time passing and contexts changed was expressed in the discussion after the screening in Lapa. Those present, in the panel and the audience, discussed the value of Domínio Público in offering a portrayal of a certain moment in social processes around urban transformations, but suggested that in 2015, there was less mobilization and less engagement than in 2013. At the same time, there was a sense that the process of urban change, and social responses to it, was still in progress, and that it would take time to understand all the outcomes and consequences. After the screening, Fausto 
commented on this perception of change, saying:

eu acho que a reação das pessoas, como você estava vendo no debate, é muito de buscar entender porque aquilo tudo acabou, porque a gente não está se mobilizando mais, porque que as pessoas continuam fazendo a mesma coisa, né, o prefeito continua removendo, a polícia continua matando, e a gente parou de reagir, parou de protestar, parou de se organizar. (I think that people's reaction, as you saw at the debate, is very much about trying to understand why all of that came to an end, why we are not mobilizing any more, why people are still doing the same things, you know, the mayor is still evicting people, the police are still killing, and we have stopped reacting, stopped protesting, stopped organizing.) (Mota, 12 August 2015, interview)

In 2016, Domínio Público’s circulation was also reignited when the Rio Olympic Games finally took place, and Rio again found itself in the global spotlight. The context had again changed, both locally, with a crisis in the UPP scheme, ${ }^{16}$ and nationally, with the Lava Jato corruption scandal ${ }^{17}$ and attempts to impeach Brazilian president Dilma Rousseff, which were ultimately successful. ${ }^{18}$

In March 2016, Domínio Público was screened by a cineclub in the northern Brazilian city of Rio Branco, state capital of Acre, sparking a short news item in the local edition of the G1 news website entitled 'Em clima político, Cineclube exibe documentário "Domínio Público" ('In a politicized climate, Cineclub shows documentary "Domínio Público") (G1 Acre 2016). One of the cineclub's coordinators, interviewed by the website, said that the film had been chosen because of its resonance with the current political context of the country, and the social and political issues it raised (G1 Acre 2016). The ongoing relevance of 
Domínio Público in 2016 was also expressed in a post on the Consciência.Net portal in January 2016, which stated

O documentário, que contou com financiamento coletivo e participação de diversos grupos audiovisuais populares, dá conta do estado das coisas neste ano de Olimpíadas. E como estamos longe de uma democracia. Tem gente morrendo, polícia impune, político sem povo. Obrigatório para quem deseja entender onde estamos. (The documentary, which was crowdfunded and included the participation of various popular audio-visual groups, deals with the state of affairs in this Olympic year. And how far we are from a democracy. There are people dying, police getting off scot-free, politicians disconnected from the people. Obligatory viewing for those who want to understand where we are.) (Barreto 2016, emphasis added)

These endorsements of the film show its importance as a snapshot of a certain moment in the history of Rio and Brazil. From the vantage point of 2016, going back to the film released in 2014 helps to shed light on the intervening period and the trajectory that led there.

Domínio Público’s 'afterlife' (Harbord 2002), and its ongoing relevance as a representation of a given conjuncture, were also apparent in the use of the project's Facebook page well into 2016. If the project's crowdfunding video 'exploded' on Facebook, as Fausto put it, the film continued to circulate and be visible, through thematic social media content shared on the social media platform about a whole range of issues linked to the local and national context. The filmmakers hired someone specifically to look after the Facebook page, and the hashtag \#DomínioPúblico was sometimes used, though not always, to label content both about the film itself and about related topics. There was no shortage of relevant material, 
with the implication of construction companies in national corruption scandals, the Mariana environmental disaster, ongoing favela removals and police violence, school occupations, and transport price increases. These topics, and others, were covered on the project's Facebook page in 2015 and 2016. However, content very directly linked to the film was also posted and commented on, as two examples from December 2015 show. This was another way of reigniting the project's visibility and its relevance to current affairs, and potentially encouraging a new burst of circulation.

On 11 December the Facebook page reposted a link to a news piece about payments from construction giant Odebrecht to Rio politicians Sérgio Cabral and Pezão, adding the commentary 'O Projeto Domínio Público alertou sobre as promíscuas relações entre o governo do PMDB, as empreiteiras envolvidas no Lava-Jato e a política de remoções. Assista ao documentário na íntegra' ('The Domínio Público project warned about the promiscuous relationships between the PMDB government, the construction companies involved in LavaJato investigation and the removals policy. Watch the documentary in full'). ${ }^{19}$ On 15 December 2015, the page posted a link to a post on the blog of well-known journalist Ancelmo Gois, on the O Globo website, about the fact that Maracanã stadium was being returned to state management, with the comment 'Outra barbarie com a cultura carioca que denunciamos em nosso Projeto Domínio Público está sendo desfeito. Em fevereiro, a Odebrecht vai devolver o Maracanã ao estado do Rio! \#AhaUhuOMaracaéNosso!' ('Another barbarity against carioca culture that we denounced in our Projeto Domínio Público is being dismantled. In February, Odebrecht will return Maracanã to the state of Rio! \#AhaUhuMaracaIsOurs'). ${ }^{20}$ As the comment suggests, there was a direct link between the story and Domínio Público, which included footage of demonstrations in front of Maracanã stadium against the privatization of the stadium. These examples show how Domínio Público used its Facebook page to affirm its contribution to documenting a particular moment in 
Rio's history, and prefiguring how that moment would subsequently play itself out at both local and national levels.

\section{Conclusion}

As I have argued in this article, Domínio Público provides a valuable snapshot of processes of urban transformation in Rio de Janeiro in 2011-14, associated with the city's hosting of two sporting mega-events in rapid succession. Through its social media presence, the project has also proved to be a broad, flexible and inclusive umbrella for portraying and reflecting on the ongoing unfolding of those processes, as well as the state of the nation, in the period following the release of its feature-length webdocumentary in 2014. My analysis of audiovisual and digital material produced by Domínio Público, as well as data collected via interviews and participant observation, has shown how the concepts of circulation and visibility were embedded in the project from its inception and became part of its critical reflection on Rio's urban transformations. In this way, Domínio Público can be understood as part of the process of urban transformation itself. Its blending and foregrounding of urban themes and digital audio-visual culture reflects a blend that characterized the moment it captures. As this article has demonstrated, the interdisciplinary and multi-faceted analysis of the content and circulation of digital works such as Domínio Público can offer valuable insights into processes of urban transformation and responses to them.

\section{References}

Acerbi, P. (2014), “"A Long Poem of Walking”: Flâneurs, vendors, and chronicles of postabolition Rio de Janeiro', Journal of Urban History, 40:1, pp. 97-115. 
Almeida, B. S. de, Marchi Júnior, W. and Pike, E. (2014), ‘The 2016 Olympic and Paralympic Games and Brazil's soft power', Contemporary Social Science, 9:2, pp. 271-83.

Alvito, M. and Zaluar, A. (1998), Um século de favela, Rio de Janeiro: Editora FGV.

d'Andréa, C. and Ziller, J. (2016), 'Violent scenes in Brazil's 2013 protests: The diversity of ordinary people's narratives', Television \& New Media, 17:4, pp. 324-34.

Bailey, K., Oliver, R., Gaffney, C. and Kolivras, K. (2017), 'Negotiating “new” narratives: Rio de Janeiro and the "media geography" of the 2014 FIFA World Cup', Journal of Sport and Social Issues, 41:1, pp. 70-93.

Barber, M. (2016), 'Funding shortage and increased violence amounts to UPP crisis', http://www.rioonwatch.org/?p=28108. Accessed 11 June 2017.

Barre, J. de L. (2016), 'Future shock: Mega-events in Rio de Janeiro', Leisure Studies, 35:3, pp. 352-68.

Barreto, Gustavo (2016), 'DOCUMENTÁRIO: Domínio Público', http://consciencia.net/documentario-dominio-publico/. Accessed 24 March 2017.

BBC News (2017), 'Brazil corruption probe: Key words and names', http://www.bbc.co.uk/news/world-latin-america-39576896. Accessed 11 June 2017. 
Beal, S. (2012), 'The substance of light: Literature and public space in belle époque Rio de Janeiro (1894-1914)', Luso-Brazilian Review, 49:2, pp. 5-27.

Bittencourt, M. C. A. (2014), 'Características de convergência na atuação do Mídia Ninja', Comunicação \& Inovação, 15:28, pp. 76-86.

Bolter, J. D. and Grusin, R. (2000), Remediation: Understanding New Media, Cambridge, MA: MIT Press.

Borst, I., Moser, C. and Ferguson, J. (2017), 'From friendfunding to crowdfunding: Relevance of relationships, social media, and platform activities to crowdfunding performance', New Media \& Society. Advance online publication. doi: $10.1177 / 1461444817694599$.

Boutros, A. and Straw, W. (eds) (2010), Circulation and the City: Essays on Urban Culture, Montreal: McGill-Queen's University Press.

Braziliarty (2014), 'MANIFEST-ACTION BRAZIL', http://www.braziliarty.org/2014/05/manifest-action-brazil/. Accessed 24 March 2017.

Brum, M. (2013), 'Favelas e remocionismo ontem e hoje: da Ditadura de 1964 aos Grandes Eventos', O Social em Questão, XVI:29, pp. 179-208.

Carvalho, B. (2014), Porous City: A Cultural History of Rio de Janeiro, Liverpool: Liverpool University Press. 
(2016), 'Introduction - Rio, city of epithets: Olympic urbanism in context', in B.

Carvalho, M. Cavalcanti and V. R. Venuturupalli (eds), Occupy All Streets: Olympic

Urbanism and Contested Futures in Rio de Janeiro, New York: Terreform, pp. 20-29.

Carvalho, B., Cavalcanti, M. and Venuturupalli, V. R. (eds) (2016), Occupy All Streets:

Olympic Urbanism and Contested Futures in Rio de Janeiro, New York: Terreform.

CETIC.br (2016), ‘TIC Domicílios e Usuários 2015 - A4 - Proporção de domicílios com acesso à internet', http://cetic.br. Accessed 22 March 2017.

Coffmann, E. (2014), 'Spinning a collaborative web’, in K. Nash, C. Hight and C.

Summerhayes (eds), New Documentary Ecologies Emerging Platforms, Practices and

Discourses, Basingstoke: Palgrave Macmillan, pp. 105-23.

Conde, M. (2005), 'Film and the "crônica": Documenting new urban experiences in turn of the century Rio de Janeiro', Luso-Brazilian Review, 42:2, pp. 66-88.

(2006), 'Screening Rio: Cinema and the desire for "the city" in turn-of-the-century Brazil', Portuguese Studies, 22:2, pp. 188-208.

Conde, M. and Jazeel, T. (2013), 'Kicking off in Brazil: Manifesting democracy', Journal of Latin American Cultural Studies, 22:4, pp. 437-50. 
Custódio, L. (2014), 'Offline dimensions of online favela youth reactions to human rights violations before the 2016 Olympics in Rio de Janeiro', in N. P. Wood (ed.), Brazil in Twenty-First Century Popular Media: Culture, Politics, and Nationalism on the World Stage, Lanham, MD: Lexington Books, pp. 139-56.

Dauvergne, P. and BL Farias, D. (2012), 'The rise of Brazil as a global development power', Third World Quarterly, 33:5, pp. 903-17.

Davis, S. (2015), 'Citizens' media in the favelas: Finding a place for community-based digital media production in social change processes', Communication Theory, 25:2, pp. 23043.

(2016), 'Case study: MídiaNINJA and the rise of citizen journalism in Brazil', in E. Gordon and P. Mihailidis (eds), Civic Media: Technology, Design, Practice, Cambridge, MA and London: MIT Press, pp. 527-32.

Dip, A. (2012), “'Isso é democracia?” pergunta cineasta; veja o documentário’, http://apublica.org/2012/09/isso-e-democracia-pergunta-cineasta-veja-documentario/. Accessed 24 March 2017.

Donaghy, M. (2015), 'Resisting removal: The impact of community mobilization in Rio de Janeiro', Latin American Politics and Society, 57:4, pp. 74-96.

Edwards, B. T. (2011), ‘Tahrir: Ends of circulation', Public Culture, 23:3\&65, pp. 493-504. 
(2016), After the American Century: The Ends of U.S. Culture in the Middle East, New

York: Columbia University Press.

Escorel, E. (2014), 'Junho e Rio em chamas - um ano depois',

http://piaui.folha.uol.com.br/questoes-cinematograficas/junho-e-rio-em-chamas-um-ano-

depois/. Accessed 24 March 2017.

Fischer, B. M. (2011), A Poverty of Rights: Citizenship and Inequality in Twentieth-Century

Rio De Janeiro, Palo Alto, CA: Stanford University Press.

Oliveira, J. P. de (2014), ‘Sobre Domínio Público’,

http://lounge.obviousmag.org/amalgama_cultural/2014/06/sobre-dominio-publico.html.

Accessed 19 March 2017.

Frangella, S. (2013), 'Afro-Brazilian culture in London: Images and discourses in transnational movements', Portuguese Studies, 29:1, pp. 78-93.

Freeman, J. (2014), ‘Raising the flag over Rio de Janeiro’s favelas: Citizenship and social control in the Olympic city', Journal of Latin American Geography, 13:1, pp. 7-38.

Freeman, J. and Burgos, M. (2016), 'Accumulation by forced removal: The thinning of Rio de Janeiro's favelas in preparation for the games', Journal of Latin American Studies. Advance online publication. doi: 10.1017/S0022216X16001942. 
Freire-Medeiros, B. (2009), 'The favela and its touristic transits', Geoforum, 40:4, pp. 58088.

Friendly, A. (2017), 'Urban policy, Social movements, and the right to the city in Brazil', Latin American Perspectives, 44:2, pp. 132-48.

G1 Acre (2016), 'Em clima político, Cineclube exibe documentário “Domínio Público”, http://g1.globo.com/ac/acre/noticia/2016/03/em-clima-politico-cineclube-exibedocumentario-dominio-publico.html. Accessed 24 March 2017.

Gaffney, C. (2010), 'Mega-events and socio-spatial dynamics in Rio de Janeiro, 1919-2016', Journal of Latin American Geography, 9:1, pp. 7-29.

(2016), 'Gentrifications in pre-Olympic Rio de Janeiro', Urban Geography, 37:8, pp. $1132-53$.

Gomes da Cunha, O. M. (2007), 'Images of favelas: Displacing (and recycling) the sites of invisibility', ReVista: Harvard Review of Latin America, VI:3, pp. 49-52.

Gregory, S. (2015), 'Ubiquitous witnesses: Who creates the evidence and the live(d) experience of human rights violations?', Information, Communication \& Society, 18:11, pp. 1378-92. 
Gutterres, A. dos S. (2014), “'It's not easy, I ask for public mobility and the government sends skull against me": An intimate account of the political protests in Rio de Janeiro (June \& July, 2013)', Anthropological Quarterly, 87:3, pp. 901-18.

Harbord, J. (2002), Film Cultures, London: SAGE.

Hight, C. (2008), 'The field of digital documentary: A challenge to documentary theorists', Studies in Documentary Film, 2:1, pp. 3-7.

Holmes, T. (2016), 'Reframing the favela, remapping the city: Territorial embeddedness and (trans) locality in "framing content" on Brazilian favela blogs', Journal of Latin American Cultural Studies, 25:2, pp. 297-319.

(2017), 'Giving visibility to urban change in Rio de Janeiro through digital audio-visual culture: A Brazilian webdocumentary project and its circulation', Journal of Urban Cultural Studies, 4:1\&2, pp. x-xx.

Holston, J. (2014), ““Come to the street!”: Urban protest, Brazil 2013’, Anthropological Quarterly, 87:3, pp. 887-900.

Horst, H. (2011), 'Free, social and inclusive: Appropriation and resistance of new media technologies in Brazil', International Journal of Communication, 5, pp. 437-62. 
Iordonova, D. (2012), 'Digital disruption: Technological innovation and global film circulation', in D. Iordonova and S. Cunningham (eds), Digital Disruption: Cinema Moves On-Line, St. Andrews: University of St. Andrews Film Studies, pp. 1-31.

Jaguaribe, Beatriz (2014), Rio de Janeiro: Urban Life through the Eyes of the City, Abingdon, Oxon and New York: Routledge.

Jaguaribe, B. and Lissovsky, M. (2009), 'The visible and the invisibles: Photography and social imaginaries in Brazil', Public Culture, 21:1, pp. 175-209.

Jaguaribe, B. and Salmon, S. (2016), 'Branding the marvelous city', in B. Carvalho, M. Cavalcanti and V. R. Venuturupalli (eds), Occupy All Streets: Olympic Urbanism and Contested Futures in Rio de Janeiro, New York: Terreform, pp. 30-58.

Leu, L. (2007), ‘Brazilianism, culture and consumption in the United Kingdom', Bulletin of Spanish Studies, 84:4\&5, pp. 645-52.

(2014), 'Deviant geographies: Black spaces of cultural expression in early 20th-century Rio de Janeiro', Latin American and Caribbean Ethnic Studies, 9:2, pp. 177-94.

Lobato, R. (2012), Shadow Economies of Cinema: Mapping Informal Film Distribution, London: British Film Institute.

Marsh, L. L. (2016), 'Branding Brazil through cultural policy: Rio de Janeiro as a creative, audiovisual city', International Journal of Communication, 10, pp. 3022-41. 
Mattos, R. C. (2013), 'Shantytown dwellers' resistance in Brazil's First Republic (18901930): Fighting for the right of the poor to reside in the city of Rio de Janeiro', International Labor \& Working-Class History, 83, pp. 54-69.

McCann, B. (2008), 'Making culture in digital Brazil', in The Throes of Democracy: Brazil Since 1989, London and New York: Zed Books, pp. 131-55.

(2014), Hard Times in the Marvelous City: From Dictatorship to Democracy in the Favelas of Rio de Janeiro, Durham, NC and London: Duke University Press.

Meade, T. A. (1996), 'Civilizing’ Rio: Reform and Resistance in a Brazilian City, 1889_ 1930, University Park, PA: Pennsylvania State University Press.

Silva, M.A. dos S. and Paz, M. de S.D. (2012), 'Distribuição gratuita de música digital como dádiva no ciberespaço', Animus - Revista Interamericana de Comunicação Midiática, 11:21, pp. 19-34.

Millington, R. and Darnell, S. C. (2014), 'Constructing and contesting the Olympics online: The Internet, Rio 2016 and the politics of Brazilian development', International Review for the Sociology of Sport, 49:2, pp. 190-210.

Mollerup, N. G. and Gaber, S. (2015), 'Making media public: On revolutionary street screenings in Egypt', International Journal of Communication, 9, pp. 2903-21. 
Mota, F., Vidal, R. and Ligeiro, H. (2014), Domínio Público, Brazil: Paêbirú Realizações Cultivadas.

Nash, K. (2012), 'Modes of interactivity: Analysing the webdoc', Media, Culture \& Society, 34:2, pp. 195-210.

Needell, J. D. (1984), 'Making the carioca belle époque concrete: The urban reforms of Rio de Janeiro under Pereira Passos', Journal of Urban History, 10:4, pp. 383-422.

(1987), 'The Revolta Contra Vacina of 1904: The revolt against "modernization" in belle-époque Rio de Janeiro', The Hispanic American Historical Review, 67:2, pp. 233-69.

(2010), A Tropical Belle Époque: Elite Culture and Society in Turn-of-the-Century Rio de Janeiro, Cambridge: Cambridge University Press.

Olinto, G. and Fragoso, S. (2011), 'Internet use in Brazil: Speeding up or lagging behind?', The Journal of Community Informatics, 7:1\&2, http://cijournal.net/index.php/ciej/article/view/835. Accessed 11 July 2013.

Oosterbaan, S. and Wijk, J. van (2015), 'Pacifying and integrating the favelas of Rio de Janeiro: An evaluation of the impact of the UPP program on favela residents', International Journal of Comparative and Applied Criminal Justice, 39:3, pp. 179-98.

Paêbirú Realizações Cultivadas (n.d.), 'Domínio Público’, http://www.paebiru.com/dominiopublico/. Accessed 1 December 2013. 
Paêbiru Realizações Cultivadas LTDA EPP (n.d.), 'Domínio Público - Sobre’, https://www.catarse.me/dominiopublico. Accessed 11 June 2017. (2013), 'Atualização do filme Domínio Público’, https://www.catarse.me/projects/981/posts/6125. Accessed 11 June 2017.

Penglase, R. B. (2016), 'Pacifying the empire of love: Sport, spectacle, security in Rio de Janeiro’, Brasiliana - Journal for Brazilian Studies, 4:2, pp. 254-82.

Perlman, J. (2010), Favela: Four Decades of Living on the Edge in Rio de Janeiro, Oxford: Oxford University Press.

Pink, S., Horst, H., Postill, J., Hjorth, L., Lewis, T. and Tacchi, J. (2015), Digital Ethnography: Principles and Practice, London: Sage Publications.

Prouse, C. (2012), 'Framing the World cUPP: competing discourses of favela pacification as a mega-event legacy in Brazil', Recreation and Society in Africa, Asia and Latin America, 3:2, https://journal.lib.uoguelph.ca/index.php/rasaala/article/view/2219. Accessed 21 March 2013.

Rekow, L. (2015), 'Police, protests, and policy in Rio de Janeiro - Mega-events, networked culture, and the right to the city', in M. Foth, M. Brynskov and T. Ojala (eds), Citizen's Right to the Digital City, Singapore: Springer Singapore, pp. 119-35. 
Richmond, M. A. and Garmany, J. (2016), “Post-Third-World city” or neoliberal "city of exception"? Rio de Janeiro in the Olympic era', International Journal of Urban and Regional Research, 40:3, pp. 621-39.

Rigby, C. (2013), 'Brazil's Mídia NINJA: Outside the axis', http://frombrazil.blogfolha.uol.com.br/2013/08/20/brazils-midia-ninja-outside-the-axis/. Accessed 12 December 2013.

Saad-Filho, A. (2013), 'Mass protests under “left neoliberalism”: Brazil, June-July 2013', Critical Sociology, 39:5, pp. 657-69.

Sampaio, A. (2014), 'Brazil's angry middle class', Survival, 56:4, pp. 107-18.

Sánchez, F. and Broudehoux, A.-M. (2013), 'Mega-events and urban regeneration in Rio de Janeiro: Planning in a state of emergency', International Journal of Urban Sustainable Development, 5:2, pp. 132-53.

Santoro, L. F. (2014), 'Vídeo e movimentos sociais: 25 anos depois', in W. Vicente (ed.), Quebrada? Cinema, vídeo e lutas sociais, São Paulo: Pró-Reitoria de Cultura e Extensão Universitária (Coleção CINUSP), pp. 39-56.

Schultz, K. (2001), Tropical Versailles: Empire, Monarchy, and the Portuguese Royal Court in Rio de Janeiro, 1808-1821, New York and London: Routledge. 
Silvestre, G. and Oliveira, N. G. de (2012), 'The revanchist logic of mega-events:

Community displacement in Rio de Janeiro's West End', Visual Studies, 27:2, pp. 204-10.

Solomon, S. (2016), 'Two ways of filming a crisis: Brazilian political cinema today', Lola, 7 , http://www.lolajournal.com/7/brazil.html. Accessed 2 January 2017.

Sørensen, I. E. (2012), 'Crowdsourcing and outsourcing: The impact of online funding and distribution on the documentary film industry in the UK', Media, Culture \& Society, 34:6, pp. $726-43$.

Sotero, P. (2014), 'Brazil's stunted revolt', Georgetown Journal of International Affairs, $15: 1$, pp. 5-13.

(2010) 'Brazil's rising ambition in a shifting global balance of power', Politics, 30:S1, pp. $71-81$.

Sotomaior, G. de B. (2015), 'Imagens, imaginários e representações no novo movimento de vídeo popular', esferas, 4:7, pp. 183-95.

Souza, G. (2012), 'Políticas culturais, vídeo digital e política de representação: Fatores para o desenvolvimento do cinema de periferia brasileiro', Revista Fronteiras: Estudos Midiáticos, 14:2, pp. 99-109. 
Spuldar, R. (2013), 'Brazil’s Mídia Ninja covers demonstrations from the inside', http://www.indexoncensorship.org/2013/08/brazils-midia-ninja-covers-demonstrations-fromthe-inside/. Accessed 10 December 2013.

Stalcup, M. (2016), 'The aesthetic politics of unfinished media: New media activism in Brazil', Visual Anthropology Review, 32:2, pp. 144-56.

Thompson, J. B. (2005), 'The new visibility', Theory, Culture \& Society, 22:6, pp. 31-51.

Valiati, V. A. D. and Tietzmann, R. (2015), 'Financiamento coletivo no cinema brasileiro: um panorama a partir da plataforma Catarse', Sessões do Imaginário, 20:33, pp. 59-68.

Valladares, Licia do Prado (1978), Passa-se uma casa: análise do Programa de Remoção de Favelas do Rio de Janeiro, Rio de Janeiro: Jorge Zahar.

(2005), A invenção da favela: do mito de origem a favela.com, Rio de Janeiro: Editora FGV.

Watts, J. (2016), 'Brazil's Dilma Rousseff impeached by senate in crushing defeat', https://www.theguardian.com/world/2016/aug/31/dilma-rousseff-impeached-presidentbrazilian-senate-michel-temer. Accessed 11 June 2017.

Whyte, M. (2013), 'Episodic fieldwork, updating, and sociability’, Social Analysis, 57:1, pp. $110-21$. 
Wilcken, P. (2005), Empire Adrift: The Portuguese Court in Rio de Janeiro, 1808-1821, London: Bloomsbury Publishing.

Williamson, T. (2016), 'Monopoly city vs. singular city: Competing urban visions', in B. Carvalho, M. Cavalcanti and V. R. Venuturupalli (eds), Occupy All Streets: Olympic Urbanism and Contested Futures, New York: Terreform, pp. 143-73.

Yúdice, G. (2013), ‘Audiovisual education practices in Latin America’s peripheries', in M. Hjort (ed.), The Education of the Filmmaker in Africa, the Middle East, and the Americas, New York: Palgrave Macmillan, pp. 239-59.

Zanetti, D. (2010), 'O “cinema de periferia” e os festivais: Práticas audiovisuais e organização discursiva', Comunicação e Sociedade, 31:53, pp. 191-214.

\section{Contributor details}

Tori Holmes is a Lecturer in Brazilian Studies at Queen's University Belfast, Northern Ireland. Her main research interests are in digital culture and the texts and practices of urban representation in Brazil, particularly relating to favelas. She has worked on blogging by favela residents, and her current research focuses on webdocumentaries relating to urban change in Rio de Janeiro. She has broader interests in digital ethnography, and ethical and methodological issues in interdisciplinary research on digital culture. She is a member of the Digital Latin American Cultures Network and one of the founders of REBRAC (European Network of Brazilianists working in Cultural Analysis).

Contact: 
Queen's University Belfast, University Road, Belfast, BT7 1NN, Northern Ireland, United Kingdom.

E-mail: t.holmes@qub.ac.uk

Tori Holmes has asserted her right under the Copyright, Designs and Patents Act, 1988, to be identified as the author of this work in the format that was submitted to Intellect Ltd.

Notes

${ }^{1}$ The definition of webdocumentary adopted here is that of a work that 'extends the documentary project into a new media space' (Nash 2012: 207). This will be discussed in more depth later in the article.

${ }^{2}$ In March 2017, Catarse is showing slightly different figures, of 1992 crowdfunders and a total of $\mathrm{R} \$ 106,181$ raised. It is not clear why this has been altered, but the figures of 2042 crowdfunders and $\mathrm{R} \$ 106,221$ are on screenshots captured in July 2014, and have been confirmed with the filmmakers.

${ }^{3}$ https://www.youtube.com/watch?v=dKVjbopUTRs.

${ }^{4}$ https://vimeo.com/98238853.

${ }^{5}$ All translations are my own.

${ }^{6}$ These figures are for the official locations of the film, uploaded by the filmmakers. Other uploads also exist.

${ }^{7}$ One write-up of the film describes it as 'a kind of Brazilian zeitgeist', see de Oliveira (2014).

${ }^{8}$ Although this is not one of the features of Domínio Público, there has been growing selfrepresentation by residents of favelas and urban periphery areas in audio-visual production and digital culture in Brazil, as this section will mention. 
${ }^{9}$ See for example Com Vandalismo (Coletivo Nigéria, 2013); Com Uma Câmera na Mão e Uma Máscara de Gás na Cara (Aymara, 2013); 20 Centavos (Tambelli, 2014); Junho O Filme: O Mês que Abalou o Brasil (Wainer, 2014); Rio em Chamas (collective production, 2014).

${ }^{10} \mathrm{https}: / /$ vimeo.com/50479054.

${ }^{11}$ https://vimeo.com/49419197.

${ }^{12}$ See https://vimeo.com/50749824 (Spanish) and https://vimeo.com/50737783 (French).

${ }^{13}$ https://www.youtube.com/watch?v=esrPoN35J1c.

14 The same sequence is repeated, with two extra interviewees added, at the beginning of the feature-length film.

${ }^{15}$ https://www.youtube.com/watch?v=UGzh7Ld3LAs.

${ }^{16}$ There have recently been cuts to security budgets in Rio de Janeiro, and favelas occupied by the UPP scheme have also been experiencing increased levels of violence (Barber 2016). ${ }^{17}$ Operação Lava Jato, or Operation Car Wash, is 'the corruption investigation launched in March 2014 into allegations that Brazil's biggest construction firms overcharged state-oil company Petrobras for building contracts' (BBC News 2017).

${ }^{18}$ Dilma Rousseff was impeached on 31 August 2016 for alleged fiscal impropriety (see Watts 2016).

${ }^{19}$ Sérgio Cabral was governor of Rio state from 2007 to 2014; Luiz Fernando Pezão was vice-governor during the same period and then succeeded Cabral as governor. Both are members of the PMDB (Partido do Movimento Democrático Brasileiro, or Brazilian Democratic Movement Party). Cabral received a prison sentence for corruption and money laundering in 2017.

${ }^{20}$ Carioca is an adjective referring to Rio de Janeiro. 